\title{
UM CAMPO DE POSSIBILIDADES: PRÁTICAS DE ENSINO DE HISTÓRIA NO CEMITÉRIO SÃO JOÃO BATISTA DE GUARABIRA-PB (2015) ${ }^{1}$
}

\author{
A FIELD OF POSSIBILITIES: \\ HISTORY TEACHING PRACTICES IN THE CEMETERY SÃO JOÃO BATISTA \\ FROM GUARABIRA-PB (2015)
}

Paulo Hipólito

\begin{abstract}
RESUMO: O objetivo da pesquisa foi demostrar como o cemitério - em particular o São João Batista de Guarabira-Pb - pode ser utilizado como instrumento para a prática de ensino de história, na elucidação de conceitos históricos, como forma de inovar o ensino de história na sala de aula, assim como alternativa de cativar o interesse dos alunos para o conhecimento histórico. O presente artigo é resultado de uma sequência didática realizada em 2015, envolvendo alunos de $8^{\circ}$ e $9^{\circ}$ ano, do Centro Educacional Dom Helder Câmara, escola ligada à rede municipal de ensino de Guarabira-Pb. A sequência se dividiu em dois momentos: aulas teóricas, em sala, e aula de campo, no cemitério. De acordo com a análise dos relatos dos alunos, podemos dizer que a sequência didática gerou resultados positivos, tais como: os alunos souberam identificar e compreender os conceitos abordados nas aulas; houve a quebra do preconceito e do medo quanto ao espaço cemiterial; os estudantes passaram a enxergar o cemitério como fonte histórica; a aula de campo ajudou na compreensão da noção de temporalidade. Desse modo, entendemos que o cemitério pode ser uma rica fonte de pesquisa, possibilitando práticas de ensino de história inovadoras e como forma de facilitar a compreensão de conceitos históricos, tais como memória, história, tempo, patrimônio e identidade, assim como suas imbricações na vida prática.
\end{abstract}

Palavras-chave: Cemitério; Ensino de história; Conceitos históricos.

\begin{abstract}
The research aims to demonstrate how the cemetery - particularly the São João Batista from Guarabira-PB- can be used like an instrument in the practice of history teaching, to explain historical concepts, as a way of innovating history teaching in the classroom, therefore it is an alternative to captivate the students' interest to the historical knowledge. This article is the result of a didactic sequence carried out in 2015 engaging 8th and 9th grade students from the Dom Helder Câmara Educational Center, in the municipal school system from Guarabira-PB. The sequence was divided in two moments: theoretical classes, in the classroom, and outdoor classes, in the cemetery. According to the analysis of the students' reports, we can say that the didactic sequence generated positive results: the students knew how to identify and understand the concepts that were taught in the classes, the

1 Este artigo constitui uma síntese da dissertação de mestrado, defendida em 2015, no Programa de Pós-Graduação em História da UFPB (PPGH/UFPB), a qual contou com a orientação do professor Dr. João Batista Gonçalves Bueno.

2 Mestre em História pelo PPGH. Graduado em História pela UEPB. Professor de História da rede municipal de ensino de Mari-Pb.
\end{abstract}


prejudice and fears in relation to cemiterial spaces were gone; the students got to understand the cemetery as historical sources; the outdoor class facilitated the comprehension of temporalities. This way, we understand that the cemetery can be a rich source of research, enabling innovative history teaching practices and as a way to facilitate the understanding of historical concepts such as memory, history, time, heritage and identity, as well as their imbrications in practical life.

Keywords: Cemetery; History Teaching; Historical Concepts.

\section{Introdução}

A produção deste artigo não constitui apenas uma síntese dos resultados advindos da pesquisa de mestrado $^{3}$, mas, antes, surge como uma contribuição para a prática de ensino de história em que professores e professoras da educação básica possam estar se inspirando para tornar as aulas de história mais significativas.

Cabe destacar que as reflexões aqui reunidas tiveram por base os resultados obtidos com a execução de uma sequência didática ${ }^{4}$, a qual envolveu aulas teóricas em sala de aula e aulas de campo realizadas junto a alunos $^{5}$ de $8^{\circ}$ e 90 anos do ensino fundamental. As aulas de campo se deram no cemitério São João Batista de Guarabira, Paraíba, no primeiro semestre de 2015. A escolha do São João Batista como palco das aulas de campo se deu pelo fato de comportar vários túmulos do século XIX, o que permitiu com

\footnotetext{
3 HIPÓLITO, P. Cemitério São João batista de Guarabira - PB: Espaço Pedagógico Para o Ensino de História. 2015, 148 f. Dissertação (Mestrado em História)- Universidade Federal da Paraíba, João Pessoa, 2015.2 Disponível em: http://tede.biblioteca.ufpb.br/bitstream/tede/8088/2/arquivo\%20total.pdf.

${ }^{4} \mathrm{~A}$ sequência didática geralmente é utilizada para o trabalho com gêneros textuais para alunos das séries iniciais na disciplina de linguagem e escrita, pois proporciona uma aprendizagem gradual conforme vai se desenvolvendo a sequência. No entanto, as outras disciplinas vêm utilizando a sequência didática para trabalhar temáticas específicas, pois a forma que se equacionam as atividades em torno de uma temática, facilita a aprendizagem, uma vez que o aluno vai se apropriando gradualmente dos conceitos e culmine na produção deles acerca do tema, de acordo com o que aprenderam. A sequência didática pode ser definida de tal forma: "De modo simples e numa resposta direta, sequência didática [...] é um modo de o professor organizar as atividades de ensino em função de núcleos temáticos e procedimentais" (ARAÚJO, 2013, p.322-323). Nesse sentido, a sequência envolve um tema central e as estratégias de ensino para se chegar ao entendimento deste tema.

${ }^{5}$ Alunos do Centro Educacional Dom Helder Câmara, escola localizada na saída de Guarabira para o município de Pirpirituba, Estado da Paraíba.
} 
que os alunos trafegassem por diversas temporalidades entre um túmulo e outro.

Com relação ao conceito de campo, este artigo se apropria das concepções de Bourdieu (1989), o qual determina campo como um espaço social onde ocorrem disputas, concorrências, conflitos pelo poder. Nesse espaço, os agentes ou instituições se conflitam para deter destaque, se sobressaírem. No entanto, estes campos são regidos por forças que são específicas, dependendo de qual campo social se refere.

Este trabalho vem dividido em três tópicos, e convém salientar que, quando faço uso do termo "campo de pesquisa", no primeiro tópico, é aceitando que, dentro desse espaço do saber, pesquisas são realizadas e há aquelas que sobressaem, seja em consistência, em ineditismo ou por apresentar um texto mais atraente.

Já no segundo tópico é utilizado o termo "campo santo" que, historicamente, já se é usado para denominar o cemitério. Mas, tendo como base as noções de "campo" de Bourdieu, o cemitério pode ser entendido como um espaço em que os agentes "lutam" para serem notados, seja através dos túmulos monumentais, das ornamentações, na rememoração ou na demonstração da fé. Basta percorrer o cemitério em dia de finados para notar que há túmulos mais ornamentados que outros, com mais flores, com mais velas acesas. A intenção é que as pessoas notem aquele túmulo se distinguirem dos demais, para que a imagem que fique seja a de que a família tem grande afeto ao ente falecido ou maior poder aquisitivo.

Por último, no terceiro tópico, é usada a categoria "campo pedagógico", uma vez que o foco do trabalho é defender estratégias pedagógicas no espaço cemiterial que se diferenciam em originalidade e, também, em potencial de aprendizagem, o que significa travar uma disputa entre as várias práticas pedagógicas que preferem outros espaços da cidade como fonte para o ensino de história. É acreditando na potencialidade pedagógica do cemitério São João Batista - ou qualquer outro - que sugiro seu uso nas práticas de ensino de história. 


\section{Um campo de pesquisa}

Os cemitérios, em nossa contemporaneidade, representam uma das mais completas fontes de informações de uma comunidade. Informações estas que são úteis tanto a historiadores quanto a antropólogos interessados em estudar os costumes e os rituais mortuários (VOVELLE, 1997, p. 324). Por ser um espaço em constante mudança, seu estudo pode ser útil para compreender as formas como uma dada sociedade pensa a morte e se relaciona com os mortos e os rituais a eles dedicados em certos momentos históricos. Por muito falar da sociedade em que se encontra inserido, o cemitério constitui uma verdadeira fonte histórica, visto que, assim como sugere Bellomo (2008, p. 13),

As sociedades projetam nos cemitérios seus valores, crenças, estruturas socioeconômicas e ideologias. Deste modo, a análise permite conhecer múltiplos aspectos da comunidade, constituindo-se em grandes fontes para o conhecimento histórico.

Devido a grande produção intelectual acerca da morte e do cemitério ocorrida nas décadas de 1970 e 1980, podemos dizer que esse período representa um marco na historiografia da mortuária e cemiterial. Nesse período, os principais historiadores franceses ligados aos Annales se dedicaram ao estudo dos cemitérios como uma extensão da concepção de morte presente no imaginário da sociedade francesa. Dentre estes autores destacam-se: Pierre Chaunu, Michel Vovelle e Philippe Ariès.

Chaunu se destacou com a obra "La mort à Paris, XVIe, XVIIe et XVIIIesiècles" (1978), a qual abordou a morte na visão do cristianismo, principalmente na concepção de purgatório para os cristãos parisiense. Le Goff, posteriormente, também abordou a temática em sua obra " $O$ nascimento do purgatório" (1993). Por seu turno, Vovelle escreveu várias 
obras sobre a morte durante a década de 1980, mas sua obra mais difundida só veio em 1991 - "Imagens e imaginário na história: fantasmas e certezas nas mentalidades desde a Idade Média até o século XX" -, que analisou os relatos de aparições de fantasmas numa perspectiva histórica de longa duração.

Sem dúvida, as duas obras de Ariès - "História da morte no ocidente" (1975) e "O homem diante a morte" (1989) - foram as mais destacadas relacionadas à evolução da concepção de morte na sociedade ocidental, também na perspectiva de uma longa duração. Para ele, as mudanças na concepção de morte são lentas e só podem ser estudadas numa escala temporal longa (ARIÈS, 2003).

No Brasil, os estudos cemiteriais e da morte teve início com os trabalhos de Clarival do Padro Valladares. O autor compreende que até a publicação de sua obra, "Arte e sociedade nos cemitérios brasileiros" (1972), as produções literárias que tratavam sobre o cemitério eram mal vistas e as falas a ele relacionadas eram macabras $\mathrm{e}$, por isso, essa temática não despertava o interesse de pesquisadores (VALLADARES, 1972).

Depois de Valladares, no ano de 1991, João José Reis publica "A morte é uma festa" (1991), obra que analisa o levante social insurgido na Bahia do século XIX, que ficou conhecido como "cemiterada". Em 1997, foi a vez de Claudia Rodrigues publicar o livro "Lugares dos mortos na cidade dos vivos", onde a autora estuda as mudanças ocorridas no espaço cemiterial ao longo do século $\mathrm{XIX}$, e o quanto essas mudanças refletiram nas práticas e rituais fúnebres e nas relações entre vivos e mortos.

Em 2000, outra importante obra obteve prestígio na historiografia cemiterial brasileira. Reunindo artigos seus e de seus orientandos, o historiador Harry Rodrigues Bellomo organizou a obra "Cemitérios do Rio Grande do Sul: arte, sociedade, ideologia", livro que aborda a riqueza de informações que um cemitério pode comportar, dando testemunho da cultura histórica da sociedade em que se encontra inserido. 
Estes autores citados foram os que produziram obras relevantes que marcaram as produções acerca da morte e dos cemitérios, sendo que suas obras se tornaram verdadeiros clássicos dos estudos cemiteriais.

\section{Um campo santo}

Segundo Araújo (2008, p. 36), os cemitérios só surgem em plena Idade Média, quando os mortos passam a lotar as dependências da igreja e o seu redor. A igreja será quem primará em preservar os túmulos, o que fará com que o cemitério se construa a sua volta - nesse momento que o lugar dos mortos se torna sagrado, um campo santo. Assim também como cita Schmitt: "[...] o cemitério é cercado por um muro, sobre o qual o bispo, quando de suas visitas paroquiais, lembra, constantemente, a necessidade de conserválo para separar o espaço sagrado do espaço profano e impedir os animais de vagar entre as sepulturas" (1999, p. 204).

A distinção de poder e status social das pessoas vivas da sociedade também se transferiu para as sepulturas. Na época medieval, os ricos e poderosos tinham espaço garantido em túmulos dentro das igrejas, principalmente próximos aos altares, pois, estes, mereciam ficar mais próximos do sagrado e, assim, poderiam ter mais chances da salvação divina. Os de pouco poder aquisitivo eram enterrados no pátio da igreja (REZENDE, 2007).

No período medieval, o cemitério representará muito mais que uma necrópole, ou seja, uma cidade restrita aos mortos. Segundo FargetteVissière (2009), os cemitérios medievais eram espaços bastante procurados e, porque não, cobiçados pelas pessoas da época. Neles eram desenvolvidas muitas atividades sociais:

De dia ou de noite, era neles que a população das maiores cidades européias buscava se divertir, quando não fixar residência provisória ou definitiva. Além disso, as necrópoles eram também um espaço de cidadania, pois lá sempre estavam juízes a comunicar sentenças, e o equivalente aos 
prefeitos de hoje a dar publicidades a suas ações. Esses locais funcionavam ainda como cartórios a céu aberto. Não que as condições ajudassem, pois já havia acúmulo de corpos e problemas de higiene e limpeza. Mas, de fato, os cemitérios atraíam. Eram um componente da urbanidade de então, construída através dos séculos e com origens bastante remotos (FARGETTE-VISSEIÈRE, 2009, p. 50).

Nota-se que os cemitérios medievais eram espaços onde ocorriam diferentes atividades. Em alguns deles, construíam-se até tabernas em suas dependências, pois, esses locais representavam autênticos lugares de sociabilidade; um verdadeiro ponto de encontro para quem procurava diversão. "Os cemitérios nesta época eram, completamente, integrados à comunidade, localizando-se no centro da mesma, servindo depois do sepultamento como pasto para o gado, local de feiras, jogos, atalhos para outras áreas e depósitos de lixo" (ROSA, 2003, p.17). Os cemitérios também eram muito procurados pelos casais, visto ser um lugar tranquilo para 0 namoro, e pelas pessoas que buscavam um relacionamento: os jovens "[...] cortejavam as moças à sombra dos ossuários e dançavam entre os túmulos a farândola, uma dança medieval muito popular, em que vários participantes fazem uma roda, que evolui para outras formações" (FARGETTE-VISSIÈRE, 2009, p. 51).

Mesmo a Igreja Católica tendo proibido muitas das práticas sociais antes desenvolvidas dentro dos cemitérios, estes ainda continuaram sendo um local de agitação até o final do século XVIII, quando os cuidados com a higiene transportarão os cemitérios para longe das cidades.

Aqui no Brasil, em cidades como Salvador e Rio de Janeiro até a primeira década do século XIX, os mortos de familiares menos favorecidos eram enterrados apenas trajando um manto cobrindo o corpo, posto que os cuidados com a higiene não haviam se tornado praxe no Brasil imperial (FARIA, 1999, p. 56). Nos cemitérios dos Pretos Novos, no Rio de Janeiro, por exemplo, os escravos eram lançados em covas muito rasas (PEREIRA, 2008) e que depois de um tempo os corpos ficavam expostos ao ar livre e as pessoas pareciam não se preocupar com isso. As pessoas conviviam meio que pacificamente com o odor exalado pelos mortos. 
Quando a preocupação com a higiene passou a ser tema central no império brasileiro, a partir da segunda década de 1850, visto que já era uma realidade na Europa, os governos passaram a aderir a esse novo padrão, reorganizando a relação entre os espaços destinados aos corpos mortos e os espaços destinados aos vivos. Segundo Reis, "uma organização civilizada do espaço urbano requeria que a morte fosse higienizada, sobretudo, que os mortos fossem expulsos de entre os vivos e segregados em cemitérios extramuros" (1991, p. 247).

Nessa perspectiva, os cemitérios foram sendo afastados das cidades, estabelecendo-se a divisão entre as cidades dos vivos e as dos mortos. "Hoje, em algumas cidades, a zona urbana cresceu tanto que de novo aproximou os mortos dos vivos" (FARIA, 1999, p. 57), como é o caso do cemitério São João Batista de Guarabira-PB.

O cemitério São João Batista, está localizado no centro da cidade de Guarabira-Pb. Com o passar do tempo, o avanço urbano acabou "engolindo" o cemitério, o que levou à construção de um novo cemitério na década de 1980. Com isso, o antigo cemitério foi inativado para construção de novos túmulos, primeiro, por falta de espaço e, segundo, por questões higienistas.

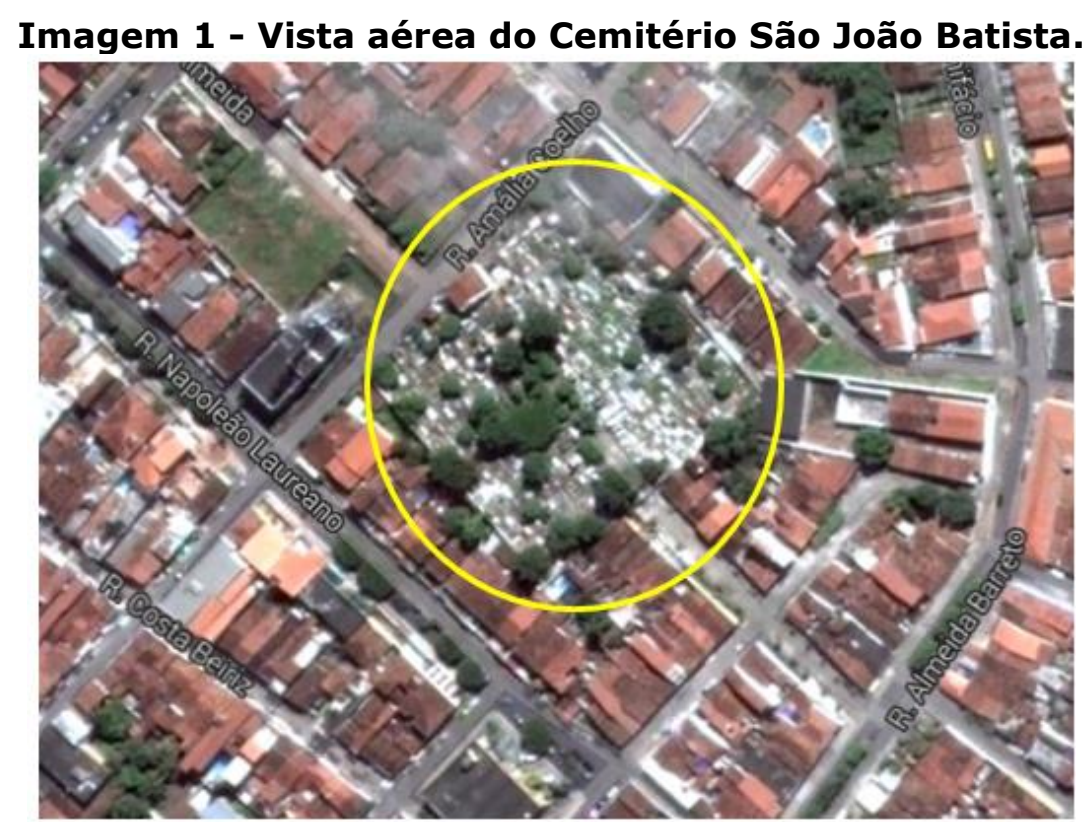

Fonte: Extraído do Google Mapas. 2015. 
Podemos caracterizar o cemitério São João Batista como sendo um cemitério misto, onde se confinam num mesmo espaço, pobres e ricos; católicos e não católicos; pessoas que despontam prestígios e os indigentes; é um espaço onde as diferenças sociais são perceptíveis. De acordo com Rezende, os cemitérios mistos "[...] são mais comuns em pequenas cidades, onde existe apenas um cemitério e a mistura de pobres e ricos torna-se inevitável, aí percebemos a desigualdade social através dos túmulos, como no caso do cemitério municipal de Cabedelo, na Paraíba" (2007, p. 32).

O cemitério São João Batista não se diferencia muito dos demais cemitérios do século XIX. Como qualquer outro, seu terreno é retangular, circundado por um muro e, na parte oposta à entrada, uma capela sepulcral. Mas, sua principal particularidade, sem dúvida, são as duas estatuas que recepcionam os visitantes, representando Adão e Eva e o episódio bíblico denominado de "o pecado original". Segundo o que está descrito no livro de Gêneses, Deus criou o mundo e colocou o homem e a mulher para viverem nele. Não havia morte nem sofrimento, pois viviam no paraíso. Mas Deus impôs uma condição: não comerem dos frutos da árvore proibida ${ }^{6}$, sob pena de serem expulsos do paraíso e a morte reinar.

\footnotetext{
${ }^{6}$ Expressão em sentido figurado para mascarar a sexualidade na bíblia. Na verdade, Adão e Eva não poderiam praticar relações sexuais, pois se assim fizessem perderiam a irracionalidade que os mantinham semelhantes aos demais animais da natureza e passariam a ter conhecimento das coisas, inclusive que estavam nus.
} 


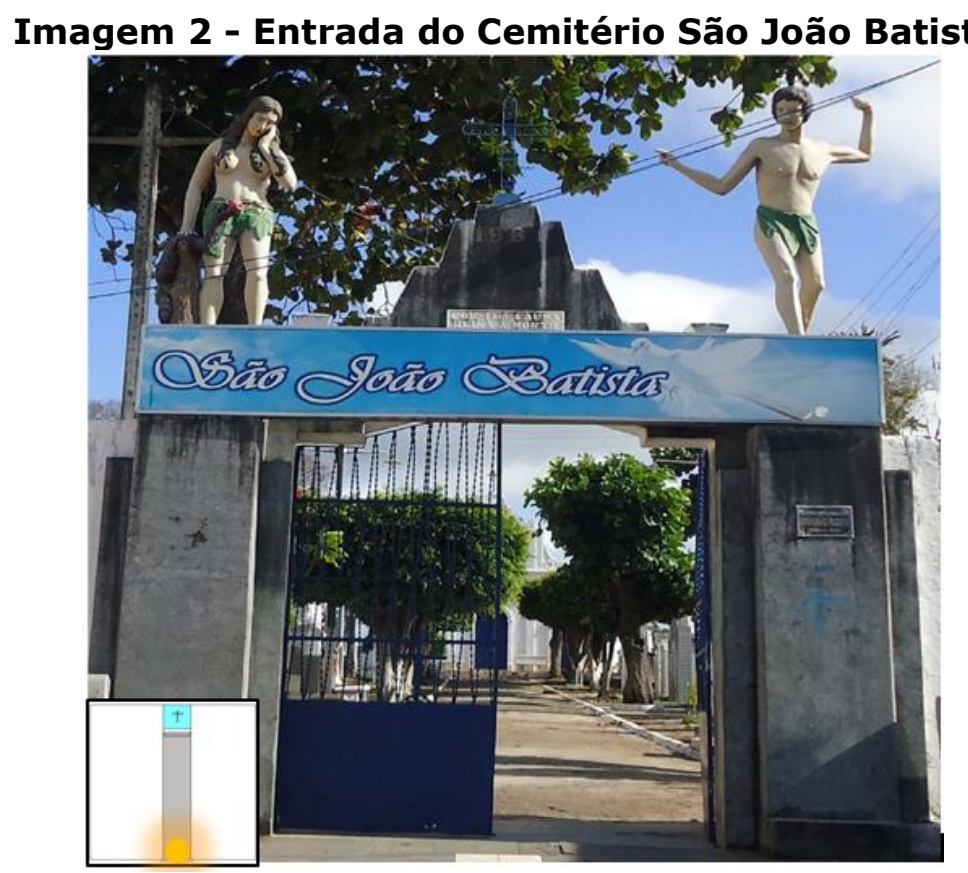

Fonte: Arquivo do Autor. 2015.

O que chama a atenção nas duas estátuas é o gesto de Adão apontando o dedo indicador para Eva, de forma acusatória. Eva, com as mãos no rosto e cabisbaixa, realça o sentimento de culpa. As estátuas simbolizam a cena bíblica em que, depois do ato sexual, Adão acusa Eva por ter Ihe induzido ao pecado. A partir desse momento, conforme relata o livro Gênesis do Antigo Testamento, o paraíso se desfez e passou a existir o sofrimento, o pecado e a morte. Para Adão, restou trabalhar para sustentar a família; em Eva recaiu o paradoxo: por um lado é exaltada como a mãe primeira, a "porta da vida"; por outro lado, seu corpo passa a representar a "porta do pecado". Assim como expões Marquetti (2007, p. 10), "nela se conjugam dois grandes verbos: viver e morrer".

Eva, representante bíblica da mulher, carrega a culpa pela morte existir, reforçada ainda mais por uma placa entre as duas estátuas, no centro da entrada do cemitério, contendo os seguintes dizeres: "Por tua causa, reina a morte". Uma placa com o nome do cemitério foi posta posteriormente, meio que encobrindo a inscrição. Mas a carga negativa permanece sobre Eva, enquanto representação do feminino na alegoria cristã da criação do mundo. 
Se levarmos em conta a expressão de Eva, ela está com a cabeça baixa voltada para a serpente e com a mão direita a acaricia, representando de qual lado a mulher estava, ou seja, do lado do mal. A serpente, como salienta Rezende (2007, p. 68), constitui símbolo do mal. "Representa o fim do pecado original, além do ódio e a inveja, e, também, a profissão de farmacêutico".

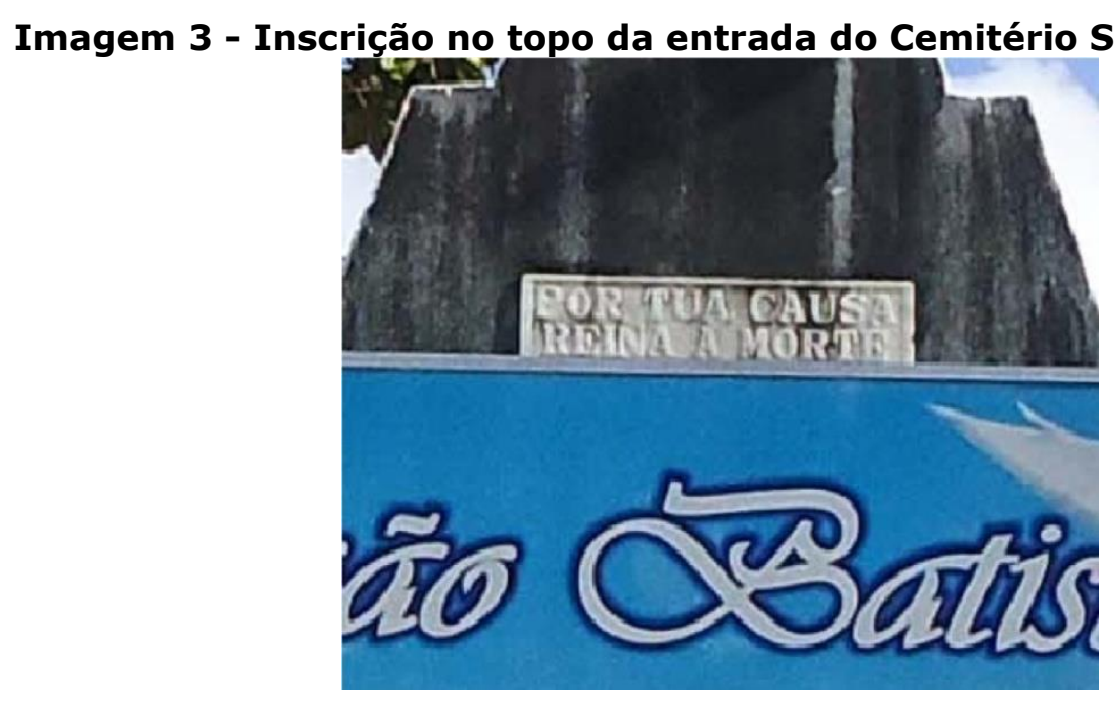

Fonte: Arquivo do Autor. 2015.

Como se nota, as duas estátuas na entrada do cemitério recepcionando os visitantes pode gerar uma forte discussão sobre gênero, para levar os alunos a pensarem como se encontra as relações entre homens e mulheres na sociedade atual; refletir as disparidades de direitos que ainda muitos aceitam como normal ou aceitável. Aí, abre espaço para pensar a violência contra a mulher, um problema histórico a ser combatido. Assim, como salienta Miceli (2011, p. 39), "ensinar História também significa comprometer-se com uma estética do mundo, onde guerras, massacres e outras formas de violência precisam ser tratados de modo crítico".

A influência romana também é um destaque presente na arquitetura tumular, podendo ser um objeto de reflexão para o ensino de história. Conforme vemos na imagem abaixo, as colunas assemelham-se as colunas de ordem toscana, que para alguns estudiosos, tem influencias da cultura dórica de arquitetura. Este estilo de coluna também é muito utilizado em 
templos católicos por ser mais simples e despojado de adereços (FERNANDES, 2008, p. 259). A ideia de uma construção tumular em forma de templo indica que aquele local é tido como sagrado.

\section{Imagem 4 -. Túmulo de influência greco-romana. Sua estrutura lembra as acrópoles gregas ou romanas da antiguidade.}

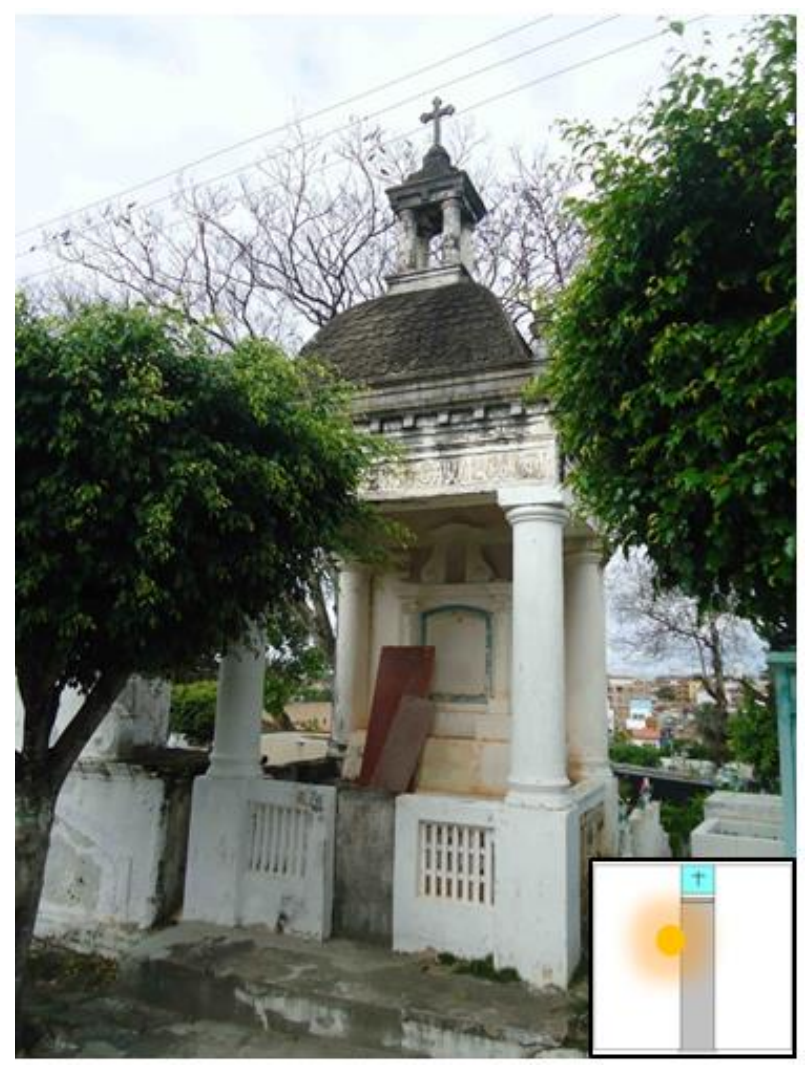

Fonte: Arquivo do autor. 2015

Segundo o historiador guarabirense Cleodon Coelho, após o Brasil se tornar independente, muitos imigrantes italianos vieram para o país para trabalhar. Dentre estes, alguns tiveram como destino a cidade de Guarabira. Denominados de "italianos patriotas", os italianos residentes no município em 1890, "[...] desejavam continuar como cidadãos italianos, obedecendo assim, aos ditames do govêrno (sic) de Sua Majestade Humberto Primeiro Rei da Itália, embora que, sujeitos as leis brasileiras" (COELHO, 1955, p. 42). O 
interessante é que o cemitério possui esses traços da cultura italiana, que demarcam a presença dos imigrantes italianos na composição da sociedade guarabirense.

A influência da arte portuguesa também está representada no São João Batista. Vemos na imagem abaixo exemplos da arte portuguesa dos azulejos. Utilizado muito fortemente ao longo da história portuguesa, para revestir pisos e paredes por sua impermeabilidade, ele foi se tornado um elemento particular da cultura portuguesa e ganhando outros espaços de utilização. Como elemento artístico, os azulejos serviram para decorar igrejas, prédios públicos e casas durante o Brasil colonial e imperial. Antes da Reforma Pombalina, os azulejos eram utilizados pelos jesuítas como material didático para o ensino de matemática (LEITÃO, 2007). Como objeto de arte, os azulejos retrataram muito fortemente cenas e personagens bíblicos. Conforme vemos na imagem, temos representada a figura de São José, com o menino Jesus no braço e a representação de Jesus Cristo, com destaque para o Sagrado Coração de Jesus. Nestes túmulos em particular são, portanto, imagens que representam os santos devotos da família ou do falecido.

\section{Imagem 5 - Arte dos azulejos. Influência da cultura portuguesa. Eles se fazem presentes em alguns túmulos, caracterizando a formação portuguesa da cidade de Guarabira}




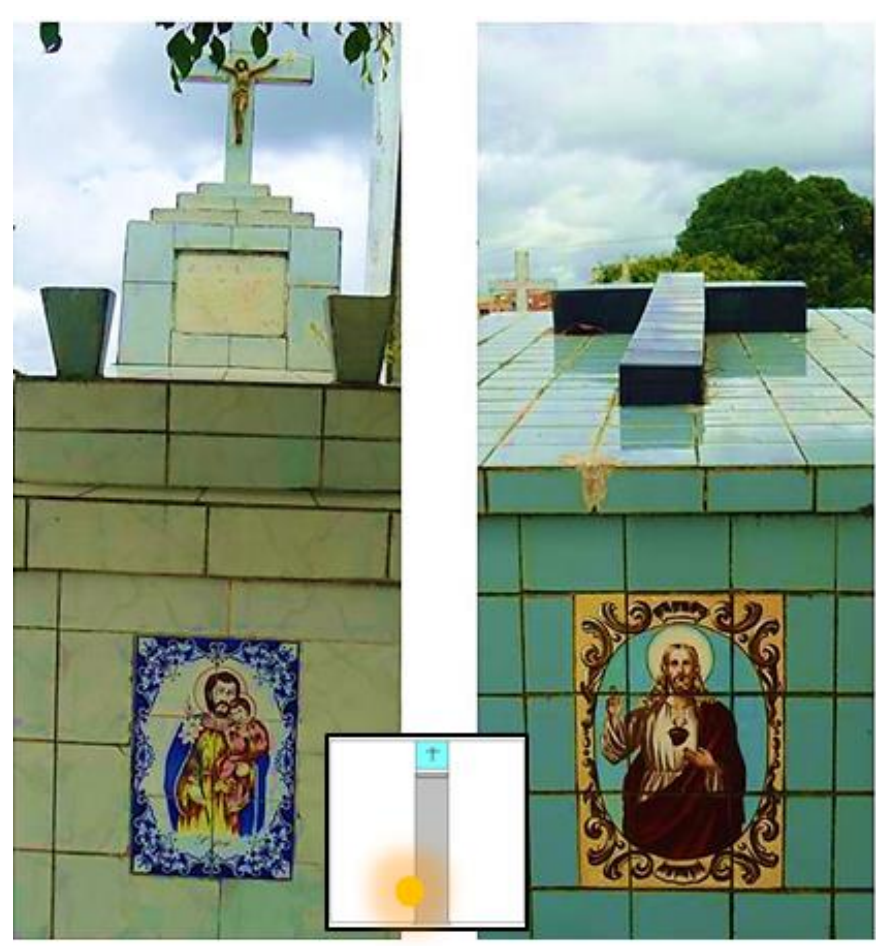

Fonte: Arquivo do autor. 2015

No túmulo pertencente à família Pimentel, o que chama a atenção é a expressão em latim, pulvis et umbra, tendo tradução livre de "pó e sombra". Na Bíblia cristã, tanto em Gênesis quanto em Eclesiástico, faz referência ao homem que veio do pó (barro) e volta ao pó. Isso porque, de acordo com a versão criacionista cristã da origem do universo, Deus teria criado o homem de barro e na sua boca teria soprado o espírito santo, dando-Ihe a vida. No entanto, com o "pecado original", o homem perdeu a imortalidade, ficando condenado a retornar ao barro: "Você comerá seu pão com o suor do seu rosto, até que volte para a terra, pois dela foi tirado. Você é pó, e ao pó voltará" (GÊNESIS 3:9).

\section{Imagem 6 - Túmulo com expressão em latim. Túmulo do médico Josué de Farias Pimentel, integrante representativo da intelectualidade guaraibirense ligado à elite local.}




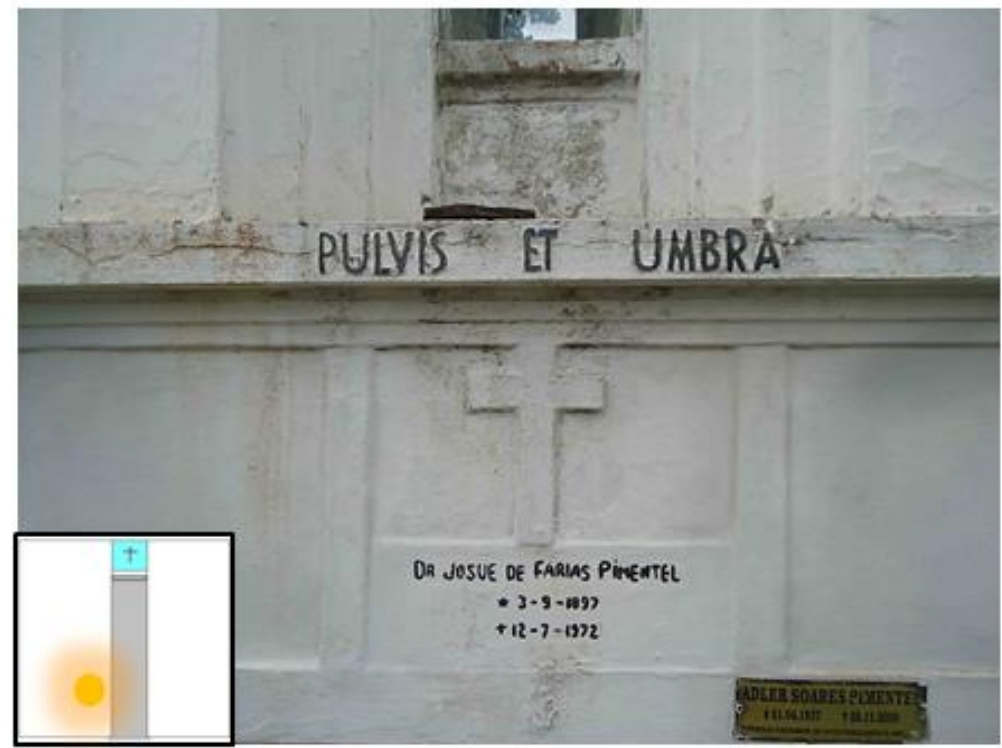

Fonte: Arquivo do autor. 2015.

Curiosamente, a expressão inscrita no túmulo tem muita semelhança com a expressão citada por Horácio (65 a.C - 8 a.C), filósofo e poeta da Roma Antiga: pulvis et umbra sumus (somos pó e sombra). Esta frase tem o mesmo sentido da frase citada por Píndaro (522 a.C - 443 a.C), poeta grego: "o homem é o sonho de uma sobra". Este poeta retrata a figura do herói "[...] dimensionado pela luz dos deuses olímpicos, sem os quais é apenas o sonho de uma sobra" (SILVA, 2005, p. 160).

Segundo Coelho (1955), os intelectuais guarabirenses - médicos, advogados, farmacêuticos, etc. - do final do século XIX e início do século XX, tinham um forte gosto pela literatura europeia. Portanto, é provável que a inspiração do médico Josué de Farias Pimentel possa ter vindo da leitura dos poemas Horácio.

Coisa curiosa também são os túmulos que imitam casas ou, talvez, pequenas capelas, conforme vemos nas imagens abaixo. São muito parecidos com pequenas moradias, inclusive com vidraças imitando portas e janelas. $\mathrm{Na}$ imagem da esquerda vemos o capricho em ornamentar as "janelas" com uma espécie de jardim suspenso. Ambas seguem os mesmos estilos arquitetônicos, o que nos leva a crer que tenha sido arquitetada por um mesmo profissional. A vantagem é a comodidade e privacidade que tem os 
familiares quando vão fazer visitas, pois dentro possui bancos e as portas contêm fechaduras, o que garante o silêncio para a oração. Além disso, as pessoas ficam protegidas da chuva e do sol e os objetos não ficam tão expostos às ações do tempo, sem contar o destaque que o túmulo concentra dentro do cemitério.

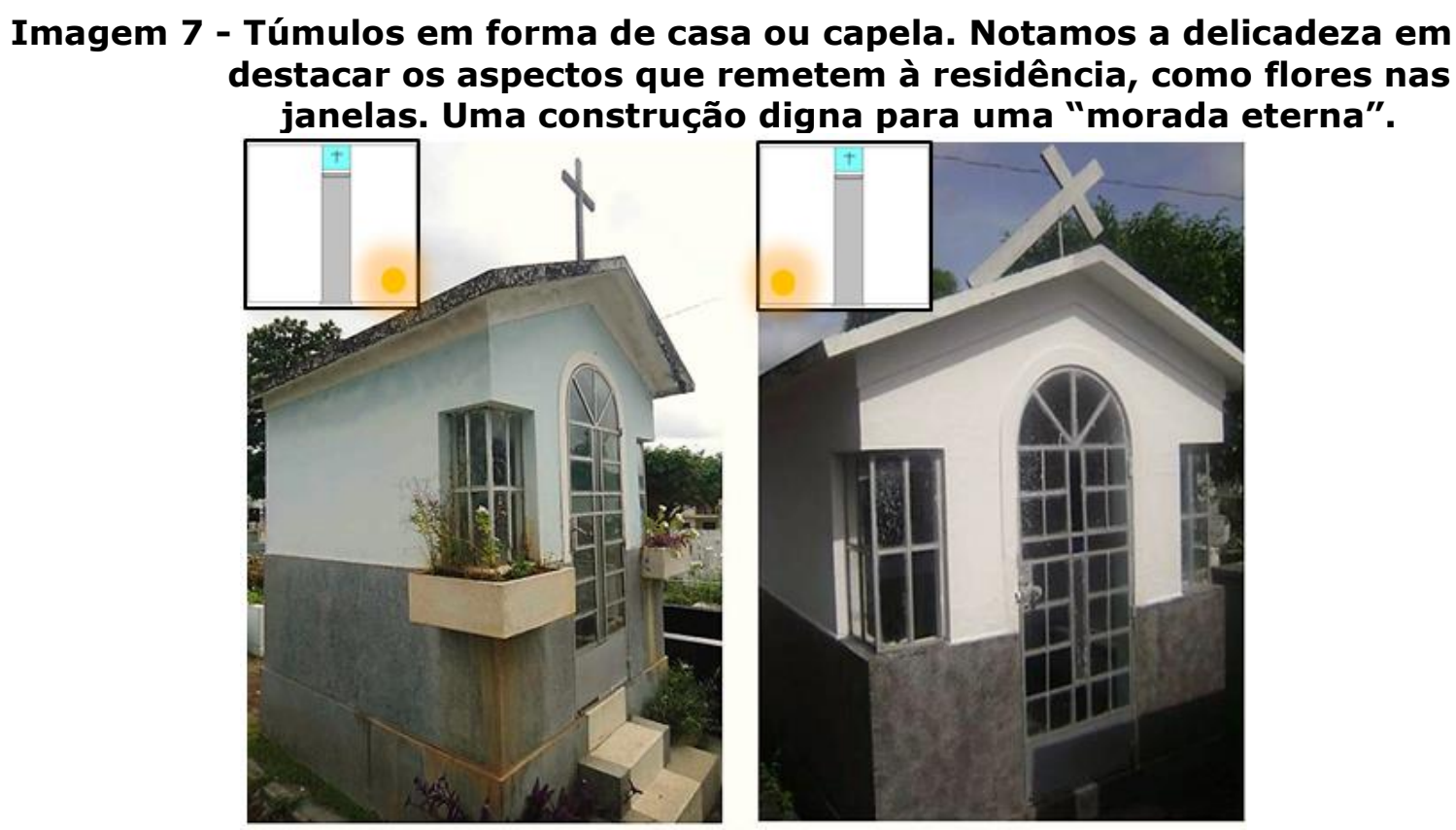

Fonte: Arquivo do autor. 2015.

Para Cymbalista, a construção dos túmulos-capelas não tem a privacidade como foco principal. O que está em primeiro plano é o significado daquilo que passa para as pessoas no exterior da construção. É preciso que as pessoas percebam a fé dos que se resguardam dentro túmulo-capela em orações:

É certo que se trata mais uma alegoria de privacidade do que da privacidade propriamente dita, pois o ritual da família reunida para seu próprio culto aos mortos deve ser percebido publicamente. Prova disso é o fato de serem raríssima as capelas totalmente opacas, elas quase sempre têm espaço de transparência, vidros, orifícios pelos quais se pode perceber o que se passa do lado de dentro (CYMBALISTA, 2002, p. 89$90)$. 
Outras formas tumulares curiosas podem ser encontradas no cemitério São João Batista de Guarabira, mas, para este estudo, julgo suficiente o que mostrei, sem deixar de considerar uma proposta de ampliação do estudo em outra oportunidade. Cabe, pois, destacar algumas das práticas presentes no cemitério que se expressam como elementos de culto aos mortos.

\section{Um campo pedagógico}

Para demonstrar algumas possibilidades pedagógicas do cemitério São João Batista para o ensino de história, foi desenvolvida uma sequência didática composta por aulas teóricas, aulas de campo e aulas avaliativas. Participaram dessa sequência alunos do $8^{\circ}$ e $9^{\circ}$ anos do ensino fundamental do Centro Educacional Dom Helder Câmara. Em cada turma a sequência didática foi executada da seguinte forma: uma aula teórica de 50 minutos; uma aula de campo no cemitério São João Batista, com 1 hora de duração; e uma aula avaliativa, onde foi pedido que os alunos relatassem, em forma de texto, suas experiências com a sequência.

Nas aulas teóricas foram abordados os seguintes temas: memória, identidade e patrimônio; a questão da morte e dos cemitérios na história; e, por último, a história do cemitério São João Batista. As aulas de campo se propuseram a quebrar com a monotonia da sala de aula e proporcionar um contato mais direto com o passado por meio da arte material dos túmulos. Com relação às aulas avaliativas, os relatos dos alunos foram os dados que serviram de base para as discussões e reflexões daqui em diante.

Uma vez analisados os relatos ${ }^{7}$ escritos dos alunos, destacaram-se alguns pontos que são pertinentes para os propósitos deste artigo. Com intuito de preservar o anonimato dos alunos, eles serão identificados pelas iniciais de seus nomes, suas idades, gênero e turmas, sendo nosso foco o teor de suas narrativas.

\footnotetext{
7 Ao todo, participaram efetivamente da sequência didática 29 alunos, sendo 10 do $8^{\circ}$ ano e 19 do 90 ano. A íntegra dos relatos está contida na dissertação do autor.
} 
O primeiro ponto a ser destacado centra-se nas datas, nomes e fatos políticos que parece ser o objeto da história para esses alunos que, assim que chegaram ao portão do cemitério, cuidaram logo em anotar as informações presentes na placa do lado direito da entrada. Assim, colocou a aluna ISR (15 anos, 90 ano A grifos meus): "[...] não pordi [pude] saber quando foi criado o cemitério de Guarabira o São João Batista mas aprendemos quando foi reformado ele foi reformado no ano de 1961 na administração do prefeito Augusto de Almeida (1960-1963) ". Para alguns alunos, o ano de 1961 foi colocado como ano de fundação em vez de reforma: "Quando chegamos aos portões do cemitério a gente ver logo a dada de fundação 1961" (JRS, 16 anos, 90ano A). No entanto, tal confusão é algo aceitável para alunos não familiarizados com pesquisa de campo e trabalho com fontes históricas. Daí a importância em possibilitar situações em que os alunos tenham contato com documentos, exercitem tirar informações deles, tentem interpretá-los e tê-los como registro do passado (KNAUSS, 2001).

Um dos pontos que considero positivo na execução da sequência didática foi o fato de boa parte dos alunos terem feito relação entre o que observaram na aula de campo e os conceitos de memória e identidade discutidos em sala de aula. A aluna FSR (13 anos, $8^{\circ} \mathrm{B}$, grifos meus) escreveu: "Memória é uma coisa que a pessoa lembra que também tem a ver com a identidade por exemplo, uma pessoa estar mortar [morta], no seu tumulo tem a sua data de nascimento e de morte a sua foto isso é identidade e memória". Percebese a tentativa de relacionar os conceitos memória e identidade a partir de suas observações aos túmulos durante a aula de campo, e conseguiu produzir um raciocínio coerente.

Já o aluno CFS (15 anos), também do $8^{\circ}$ ano $B$, e que faltou a aula no cemitério, falou da memória citando exemplo de experiência afetiva: "Memória é aquilo que você é selembrado [lembrado] pessoas que morre da sua família tipo o avo de meu amigo que era uma pessoa legal ele brincava de bola mais um certo dia ele faleceu e com a morte dele a família dele estava sofrendo muito pela morte do avo do garoto" (grifos meus). Talvez o avô do seu amigo fosse seu amigo e jogassem juntos ou significasse a perda mais 
próxima que o aluno tenha tido, mas o ar de saudade de um tempo passado impera no seu relato. No seu relato desponta uma espécie de memória afetiva, a qual Benjamin (1987) traz como sendo as experiências mais sensíveis que ficou marcada na vida de uma pessoa, que surgem no presente como um "relampejar".

Por mais simples que seja essa relação do conteúdo ensinado com a experiência do aluno, sinaliza uma operação consciente de aplicação da teoria à prática, num exercício que tira o sujeito da passividade e o faz pensar seu passado. "Quando o aluno procura explicações para uma situação do passado à luz da sua própria experiência, mesmo sem apreciar as diferenças entre as suas crenças e valores e as de outra sociedade, revela já um esforço de compreensão histórica" (BARCA; GAGO, 2001, p. 241).

Por sua vez, a aluna ISL (14 anos, 90A) procurou relacionar a memória e a identidade com o patrimônio: "[...] aprendi que o cemitério tem tudo a ver com: memória, identidade e patrimônio que são pessoas que falecem, que era muito importante, e que patrimônio é tudo aquilo que nós temos". Para além de algumas confusões é importante considerar o esforço em tentar relacionar os conceitos com o contexto do cemitério que estudamos. Dois alunos, no entanto, chamaram a atenção pela sensibilidade e pensamento crítico referente ao patrimônio e sua preservação: "[...] o que eu acho um caso perdido é que os prefeitos não podem tocar no cemitério para reformar, pois, devia ser sua a responsabilidade, fora isso o cemitério era muito ótimo só o que faltava era uma reforma" (DDP, 17 anos, 8º).

Assim como a resposta do aluno acima, outros tiveram a mesma indignação acerca dos túmulos que estão entrando em ruínas no cemitério São João Batista. Mais indignados ficaram quando foi explicado que os túmulos se tratavam de um patrimônio privado e, sendo assim, só a família poderia restaurar os túmulos ou, fosse o caso, autorizar para que outra pessoa assim procedesse. Nisso, temos duas noções de patrimônio que se contrastam: público e privado. Público com relação ao cemitério como patrimônio público da cidade de Guarabira e privado com relação aos túmulos como propriedade das famílias. Nessa lógica de indignação, o aluno JRS (12 
anos, $8^{\circ} \mathrm{B}$ ) apontou a importância da preservação dos túmulos e a solução para o problema: "Na minha opinião, os familiares ou os órgãos públicos deviam reformar os túmulos porque assim parte da história de Guarabira vai sendo destruída".

A partir das opiniões dos alunos, tem-se a possibilidade de trabalhar a educação patrimonial de forma interdisciplinar e extraclasse, que pode se desenvolver através de visitas-guiadas aos espaços públicos que preservam a memória e a história do lugar. A educação patrimonial deve partir da problematização desses lugares institucionalizados como patrimônio; questionar a função dos atores envolvidos nesse processo, os seus interesses, o papel do Estado (FONSECA, 1992) e, além disso, estender a ideia de patrimônio para além dos lugares institucionalizados como tal.

Levando em consideração os relatos dos alunos, o professor de história pode propor uma atividade de pesquisa ou para buscar respostas das autoridades quanto à preservação dos túmulos do século XIX, ou até mesmo propor que os alunos em equipe buscasse encontrar os familiares a quem os túmulos pertencem, e então estariam agindo diretamente para mudar uma realidade, agindo como sujeitos atuantes na vida social - ou, como se prefira, atuando como sujeitos históricos (FREIRE, 1996).

Outros dois alunos destacaram a parte arquitetônica dos túmulos, relacionando a grandiosidade da construção como forma de demonstração do poder econômico, o que está relacionado também com a manutenção da identidade por meio da arquitetura tumular. Nesse sentido, o aluno JSC (14 anos, $9^{\circ} \mathrm{A}$, grifos meus) tratou de registrar que "[...] algumas pessoas fazem o tumulo enorme para demostrar [demonstrar] a ostentação pois [após] a morte". Na mesma linha de pensamento o aluno EDS (18 anos, $9^{\circ} \mathrm{A}$, grifos meus) colocou: "os túmulos que tem tumbas os mulumentos [monumentos] esprendosos [esplendoroso] que significa ostentação que a pessoa que foi sepultada era muito importante". Algo curioso nas falas desses dois alunos é a utilização do termo "ostentação", mencionado para expressar o poder econômico. Não é forçoso relacionar a popularização do termo com o advento do estilo musical popularmente conhecido como "funk ostentação", surgido 
em São Paulo no ano de 2008 e que ganhou o Brasil, tendo como marco de consolidação a morte de um dos seus maiores representantes, o Mc Daleste.

O motivo do sucesso do funk ostentação entre os jovens se explica porque grande parte dos representantes do estilo musical são jovens adolescentes - às vezes até crianças - que cantam em suas músicas e videoclipes seu poder econômico, por meio da exibição dos seus bens, como carros, motos, joias, dinheiro, etc. Segundo Dayrell (2002), o funk constitui para os jovens como um espaço de sociabilidade construída por eles e para eles, ou seja, a questão da identidade e da visão de mundo dos jovens estão imbricados no gosto musical para o funck.

Paulo Freire (1996) dizia que era preciso conhecer o mundo do aluno, fazer uma leitura da leitura de mundo que eles trazem para sala de aula; falar a língua do aluno na exposição do conteúdo. Portanto, ainda hoje, apresenta-se como um desafio para os professores, tomar conhecimento das formas de se expressar dos alunos para melhor entendê-los e atendê-los em suas necessidades. Conhecendo nossos alunos, construindo a aprendizagem junto com eles, o processo de ensino-aprendizagem se torna mais dinâmico, significativo e condizente com a realidade vivida.

Também me chamou a atenção o depoimento da aluna ISR. Primeiramente, ISR falou de sua mudança de concepção com relação ao cemitério, uma vez que a aluna, no início das aulas teóricas, foi uma das que mais temiam ir ao cemitério, mesmo sem nunca ter visitado um - aqui surge novamente a questão das ideologias com relação à morte. Assim comentou:

\begin{abstract}
No cemitério, e podir [pude] ver que o cemitério, não é um lugar frio sem nenhuma coisa assustadora mas sim um lugar cheio de história, lembranças de varias pessoas [...] nunca tive tanto interesse em ir lá pois achava que era um lugar triste mas naquela sexta-feira dia 12- do 06 de 2015 percebir [percebi] que o cemitério é um lugar repleto de enteses[interesses?] e argumentos para se estudar de ser pesquisado [...] (ISR, 15 anos, $9^{\circ} \mathrm{A}$, grifos meus).
\end{abstract}

Conforme o relato, se tem noção do impacto que representou essa aula no cemitério para a mudança de concepção para a aluna, tanto que a ida ao 
cemitério foi registrada como um marco em sua vida. Ora, quando algo representa um marco - seja para um indivíduo ou uma sociedade - a primeira coisa que se faz é registrar a data do acontecimento para ser lembrado na posterioridade. Portanto, a aluna cuidou em destacar "aquela sexta-feira".

A aluna também relatou o que encontrou no cemitério: "lá encontramos túmulos de séculos passados ainda intacto túmulos do século 19 e hoje no século 21 ainda estão lá mas tem tantos túmulos bonito de origem de suas características, grega, italiana, africana, encontramos até túmulos que parecia igrejas, castelos, casa, etc...". Interessante a forma que a aluna organizou sua fala relacionando passado e presente, a sensatez em citar as características culturais dos túmulos, a maneira que observa as mudanças, ou seja, ela se mostrou sensível ao trafegar pelas temporalidades. O termo "ainda estão lá", quando a aluna se referiu aos túmulos do século XIX, indica que ela possuiu uma noção de ruptura, ou seja, os túmulos poderiam não mais existir. Para que serve a história senão para fazer os alunos compreenderem as rupturas e permanências das práticas humanas que transformam o espaço? Até mais que os alunos, os professores de História devem ter em mente que, como bem disse Winock,

\begin{abstract}
A história [...] contribui, em primeiro lugar para entendermos o mundo presente. Como em uma cidade coexistem através da arquitetura, das crenças, dos mitos e superstições do passado e presente. A história ajudaria a decifrar esta paisagem. A História também ajudaria a entender que além de tudo o que está gravado na pedra ou sepultado debaixo da terra, as atitudes e os comportamentos humanos perante a doença, o sofrimento, a morte, as idades da vida não são eternos. Pertencem à temporalidade, têm um principio e um fim. A história é a arte de aprender que o que é nem sempre foi, que o que não existe pôde alguma vez existir; que o novo não o é forçosamente e que, ao contrário, o que consideramos por vezes eterno é muito recente. Esta noção permite situarmo-nos no tempo, relativizar o acontecimento, descobrir as linhas de continuidade e identificar as rupturas (WINOCK apud CAINELLI, 2010, p. 18).
\end{abstract}

O aluno GMN (14 anos, 90A) ressaltou que gostou ainda mais da experiência quando encontrou o túmulo da família Osmar de Aquino. Diria até que o nome de Osmar de Aquino, advogado e político durante a primeira 
metade do século $X X$, ressoa como herói mítico para a sociedade guarabirense. Em sua homenagem deram nome à escola (Centro Educacional Osmar de Aquino), conjunto residencial (Conjunto Osmar de Aquino) e até o Campus III da Universidade Estadual da Paraíba recebeu seu nome (Centro de Humanidades Osmar de Aquino).

O contato dos alunos com os túmulos das figuras guarabirenses que deram nome a elementos urbanos da cidade - instituições, ruas, bairros, sítios, praças, etc. - serviu como exercício de desmitificação e humanização desses "heróis construídos". Diante de seus túmulos, os alunos tiveram a "prova" de que existiram de fato, ou melhor, que morreram - destino irrefutável de todo ser humano.

O fato de não ceder nenhum tipo de material didático aos alunos não significou problema quando verificamos que os relatos foram produzidos demonstrando habilidades argumentativas de suas experiências e opiniões acerca do que aprenderam ou acharam interessante, sem que houvesse foco na "decoração". E, por outro lado, proporcionar aos alunos momentos para eles produzirem textos narrativos relatando experiências passadas, história do lugar, sua biografia, é primordial para que se formem alunos-leitores; e, importante também, "[...] para mostrar aos alunos que eles próprios podem produzir uma narrativa com conteúdo histórico" (FERMIANO; SANTOS, 2014, p. 110).

E, como os alunos foram capazes de construírem um texto narrando suas experiências e sua compreensão sobre o que foi debatido em sala e observado no cemitério, isso demonstrou que usaram a cognição, o pensamento, para dialogar a teoria com a prática, tendo por base suas visões de mundo e de si mesmos. Essa compreensão resulta em algo novo, muitas vezes em mudanças de concepção, como observamos na maioria dos relatos. Nesse ato de narrar os alunos assumiram autonomia, se colocaram como sujeitos ativos.

Quando se fala em sujeito ativo, trata-se de alguém que constrói suas próprias categorias de pensamento, que compara, exclui, ordena, categoriza, classifica, reformula, comprova, formula hipóteses, tanto numa ação interiorizada, 
em pensamento, quanto numa ação concreta, cujo comportamento seja observável (CAIMI, 2007, p. 26).

As aulas teóricas e de campo se mostraram significativas para os alunos pelo fato de apenas um aluno alegar que não gostou e, como já explicamos, o mesmo não havia passado pelo processo de sensibilização como ocorreu com os demais. E como essa avaliação corresponde ao geral - a sequência didática como um todo, envolvendo as aulas e os relatos dos alunos -, deuse para perceber que os alunos gostaram porque se mostrou algo diferente, algo que os mobilizaram, que os tiraram da monotonia da sala de aula.

\section{Considerações Finais}

Considerando a experiência nas aulas teóricas e práticas da sequência, e tomando por base o relato dos alunos, percebeu-se que, em todas as turmas em que as aulas foram ministradas, os alunos demonstravam medo e resistência ao cemitério. Eles o enxergavam como sendo um lugar onde só reinava a morte, lugar da putrefação, do medo, da tristeza. No entanto, quando terminaram-se as aulas, os alunos já puderam demonstrar interesse em visitar o cemitério, para verificar tudo aquilo que foi falado em sala. Isso indica uma quebra de preconceitos com relação ao cemitério e revela que, muitos dos preconceitos reproduzidos ainda na sociedade atual, só precisa ser abordado em sala de aula, não ser silenciados. Nesse sentido, a experiência com a sequência didática envolvendo o cemitério fez brotar uma expectativa: se mostra como uma proposta didática que pode ser utilizada por professores de história em qualquer cidade. Conforme sentencia Koselleck (2006, p. 307), "não há expectativa sem experiência, não há experiência sem expectativa".

Isso é importante porque temos muitos trabalhos publicados que abordam a questão do ensino de história, apenas, teoricamente, isto é, discutindo apenas como ele deve ser; as habilidades que os professores precisam ter; o que os alunos devem aprender. No entanto, acaba ficando uma lacuna a ser considerada: o que pode ser realizado para melhorar o 
ensino-aprendizagem de história? Quais os caminhos a seguir? Quais atividades realizar? Portanto, que este estudo sirva de proposta para outros professores - e não só de história -; uma contribuição de como proceder, e que possam ir além, descobrir novas formas de trabalhar a história no espaço cemiterial.

Se refletida a sequência didática como foi trabalhada, não se trata de nenhuma atividade mirabolante, complexa, exaustiva e de gastos econômicos consideráveis. Constitui uma sequência didática simples e possível de ser realizada em qualquer escola, em qualquer turma do ensino fundamental ou médio, bastando para isso que a cidade tenha um cemitério - não precisa ser antigo ou ter túmulos monumentais - e o professor a vontade de sair do habitual. Portanto, não há muitas dificuldades que impeçam que a prática de ensino de história no cemitério, entendendo-o como fonte, aconteça com frequência no ensino básico - fundamental I e II e ensino médio.

Pensando no ensino de história, nunca é demais abordar práticas de ensino que resultem em aprendizagem significativas para o aluno, até para que a história quebre o preconceito que muitos têm acerca da História como disciplina morta e sem graça, sem muita coisa interessante a mostrar que sirva a vida prática de quem aprende. O grande desafio é despertar o prazer nos alunos em estudar/aprender História, assim como o tem os historiadores que se debruçam sobre os documentos e descobrem novas experiências humanas (SILVA, 2003). Mas, para isso, é preciso também que o professor tenha prazer em ensinar e se entusiasmar quando um aluno ou aluna demonstra que aprendeu - não só decorou - o que ele ensinou. Por isso, mesmo não sendo comum concluir um texto com uma citação, é pertinente encerrar este trabalho trazendo o relato do aluno JAS (15 anos, $8^{\circ} \mathrm{B}$ ), que havia faltado à aula de campo, mas relatou o que aprendeu com as aulas em sala.

Eu aprendi na sua aula que a história não é qualquer coisa é muito importante. Agente tem que vivenciar a história a história faz parte da sociedade pra o mundo chegar onde ele chegou ele tem uma história agente tem também tem uma 
história. O passado tem muitas coisas lindas e a história faz parte disso.

\section{Referências}

ARAÚJO, Denise Lino de. O que é (e como faz) sequência didática? Entrepalavras, Fortaleza, ano 3, n. 1, p. 322-334, jan./jul. 2013.

ARAúJO, Thiago Nicolau de. Túmulos celebrativos do Rio Grande do Sul: múltiplos olhares sobre o espaço cemiterial (1889 - 1930). Porto Alegre: EDIPUC-RS, 2008.

ARIÈS, Philippe. História da morte no ocidente da Idade Média até aos nossos dias. Rio de Janeiro: Ediouro, 2003.

BARCA, Isabel; GAGO, Marília. Aprender a pensar em história: um estudo com alunos do $6^{\circ}$ ano de escolaridade. Revista Portuguesa de Educação, Braga, Portugal, v. 14, n. 1, p. 239-261, 2001.

BELLOMO, Harry Rodrigues (org.). Cemitérios do Rio Grande do Sul: arte, sociedade, ideologia. 2. ed. Porto Alegre: EDIPUCRS, 2008.

BENJAMIN, Walter. Obras escolhidas. Magia e técnica, arte e política. v.1. São Paulo: Brasiliense, 1987.

BOURDIEU, Pierre. O poder simbólico. Tradução de Fernando Tomaz. Rio de Janeiro: Editora Bertrand Brasil, 1989.

CAIMI. Flávia Eloisa. Porque os alunos (não) aprendem história? reflexões sobre ensino, aprendizagem e formação de professores de história. Revista Tempo, Brasília, v. 11, n. 21, p.17-32, 2007.

CAINELLI, Marlene. O que se ensina e o que se aprende em história. In: OLIVEIRA, M. M. D. (coord.). História: ensino fundamental. Brasília: Ministério da Educação, 2010. (Coleção Explorando o Ensino, v. 21). p.1734.

CHAUNU, Pierre. La mort à Paris, XVIe, XVIIe et XVIIIesiècles. Paris: Fayard, 1978.

COELHO, Cleodon. Guarabira através dos tempos. Obra do professor Ceodon Coelho. Guarabira: Livraria Nordeste, 1955.

CYMBALISTA, Renato. Cidade dos vivos: arquitetura e atitudes perante a morte nos cemitérios do Estado de São Paulo. São Paulo: Annablume: Fapesp, 2002. 
FARGETTE-VISSIĖRE, Séverine. Os animados cemitérios medievais. História Viva, São Paulo, n. 67, p. 48-52, maio 2009.

FARIA, Sheila de Castro. Viver e morrer no Brasil colônia. São Paulo: Moderna, 1999.

FERMIANO, Maria Belintane; SANTOS, Adriane Santarosa dos. Ensino de história para o fundamental 1: teoria e prática. São Paulo: Contexto, 2014.

FERNANDES, Lídia. A ordem toscana na Lusitânia ocidental: problemática e caracterização do seu emprego: a propósito das peças reutilizadas da Igreja de S. Pedro de Lourosa (Coimbra). Revista Portuguesa de Arqueologia, Lisboa, v. 11, n. 2, p. 231-270, 2008.

FONSECA, Maria Cecília. Construções do passado: concepções sobre a proteção do patrimônio histórico e artístico nacional (Brasil: anos 70-80). 1992. Tese (Doutorado em Sociologia) - Universidade de Brasília, Brasília, 1992.

FREIRE, Paulo. Pedagogia da autonomia: saberes necessários à prática educativa. São Paulo: Paz Terra, 1996.

KNAUSS, Paulo. Sobre a norma e o óbvio: a sala de aula como lugar de pesquisa. In: Nikitiuk, S. M. L. Repensando o ensino de história. 4. ed. São Paulo: Cortez, 2001. p. 26-46.

KOSELLECK, Reinhart. Futuro passado: contribuição à semântica dos tempos históricos. Tradução de Wilma Patrícia Maas e Carlos Almeida Pereira. Rio de Janeiro: Contraponto: Ed. PUC-Rio, 2006.

LEITÃo, Henrique. Azulejos que testemunham uma tradição de ensino científico. In: SIMÕES, Carlota (org.). Azulejos que ensinam. Coimbra: Museu Nacional de Machado de Castro: Universidade de Coimbra, 2007. p. 16-33.

MARQUETTI, Flávia Regina. Olhos de serpente. Revista Ártemis, João Pessoa,v. 7, p. 1-12, dez. 2007.

MICELI, Paulo. Uma pedagogia da história? In: PINSKY, Jaime. O ensino de história e a criação do fato. 14. ed. São Paulo: Contexto, 2011. p. 37-42.

PEREIRA, J. C. M. S. Uma reprodução simbólica do universo social: o sepultamento de escravos no cemitério do Pretos Novos, no Rio de Janeiro dos séculos XVII a XIX. Sankofa, São Paulo, n. 1, p. 20-46, jun. 2008.

REIS, João José. A morte é uma festa: ritos fúnebres e revolta popular no Brasil do século XIX. São Paulo: Companhia das Letras, 1991. 
REZENDE, Eduardo Coelho Morgado. Cemitérios. São Paulo: Editora Neclópolis, 2007.

ROSA, Edna Terezinha da. A relações das áreas de cemitérios com o crescimento urbano. 2003. Dissertação (Mestrado em Geografia) Universidade Federal de Santa Catarina, Florianópolis, 2003.

SCHMITT, Jean-Claude. Os vivos e os mortos na sociedade medieval. Tradução de Maria Lucia Machado. São Paulo: Cia das Letras, 1999.

SILVA, Amós Coelho da. Os jogos e as instituições sociais em sociedades arcaicas e primitivas. In: LESSA, Fábio de Souza; BUSTAMANTE, Regina Maria da Cunha (org.). Memória \& festas. Rio de Janeiro: Mauad, 2005. p. 157-164.

SILVA, Marcos A. História: o prazer em ensino e pesquisa. São Paulo: Brasiliense, 2003.

VALLADARES, Clarival do Prado. Arte e sociedade nos cemitérios brasileiros. Brasília: Imprensa Nacional, 1972. v. 2.

VOVELLE, Michel. Imagens e imaginário na história: fantasmas e incertezas nas mentalidades desde a Idade Média até o século XX. São Paulo: Ática, 1997. 